\title{
BioéthiqueOnline
}

\section{When Two Worlds Meet: A Response to Heesters}

\section{Jacques Quintin}

Volume 4, 2015

Reçu : 22 Apr 2015; publié : 25 Jun 2015; éditrices : Maude Laliberté \& Aliya Affdal; travail creatif discuté : AM Heesters. Healthy as a trout as delicate as a dragon-fly BioéthiqueOnline 2014, 3/13

URI : https://id.erudit.org/iderudit/1035502ar

DOI : https://doi.org/10.7202/1035502ar

Aller au sommaire du numéro

Éditeur(s)

BioéthiqueOnline

ISSN

1923-2799 (numérique)

Découvrir la revue

Citer cet article

Quintin, J. (2015). When Two Worlds Meet: A Response to Heesters

BioéthiqueOnline, 4. https://doi.org/10.7202/1035502ar

\section{Résumé de l'article}

Ce texte est un commentaire à propos de l'article de Heesters, " Healthy as a trout - as delicate as a dragon-fly ", dans lequel elle relate son expérience de la maladie. Son texte montre qu'il existe deux mondes difficilement conciliables : celui des soignants et celui des soignés. La question est celle de savoir comment concilier ces deux univers de sens. Recevoir des soins est certes nécessaire, mais ce n'est pas suffisant dans la mesure où les soignés sont aussi motivés par le besoin de comprendre leur existence mise à mal en raison de la maladie. Le contact des sciences humaines, toutes ces formes d'expression qui touchent à la condition humaine, est d'un grand secours pour permettre aux soignants d'accompagner les personnes malades afin que celles-ci puissent mettre des mots sur leur vécu. Les humanités permettent de réduire l'écart entre le monde médical et le monde vécu. Et le texte de Heesters en est un exemple.
Droits d'auteur (c) J Quintin, 2015

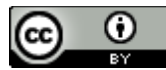

Ce document est protégé par la loi sur le droit d'auteur. L'utilisation des services d’Érudit (y compris la reproduction) est assujettie à sa politique d'utilisation que vous pouvez consulter en ligne.

https://apropos.erudit.org/fr/usagers/politique-dutilisation/ 


\title{
When Two Worlds Meet: A Response to Heesters
}

\author{
COMMENTAIRE / COMMENTARY \\ Jacques Quintin ${ }^{1}$
}

Reçu/Received: 22 Apr 2015

Publié/Published: 25 Jun 2015

Éditrices/Editors: Maude Laliberté \& Aliya Affdal

Travail creatif discuté/Creative Work discussed: AM Heesters. Healthy as a trout - as delicate as a dragon-fly

BioéthiqueOnline 2014, 3/13

\section{J Quintin, Creative Commons Attribution 4.0 International License}

\section{Résumé}

Ce texte est un commentaire à propos de l'article de Heesters, "Healthy as a trout - as delicate as a dragonfly ", dans lequel elle relate son expérience de la maladie. Son texte montre qu'il existe deux mondes difficilement conciliables : celui des soignants et celui des soignés. La question est celle de savoir comment concilier ces deux univers de sens. Recevoir des soins est certes nécessaire, mais ce n'est pas suffisant dans la mesure où les soignés sont aussi motivés par le besoin de comprendre leur existence mise à mal en raison de la maladie. Le contact des sciences humaines, toutes ces formes d'expression qui touchent à la condition humaine, est d'un grand secours pour permettre aux soignants d'accompagner les personnes malades afin que celles-ci puissent mettre des mots sur leur vécu. Les humanités permettent de réduire l'écart entre le monde médical et le monde vécu. Et le texte de Heesters en est un exemple.

Mots clés

soins de la santé, maladie, phénoménologie, humanisme

\begin{abstract}
Summary
This is a commentary on the article of Heesters, "Healthy as a trout - as delicate as a dragon-fly", in which she describes her experience of illness. Her text shows that there are two worlds that are difficult to reconcile: that of caregivers and sick people. The question is how to reconcile these two worlds of meaning. To receive good care is certainly necessary, but not sufficient to the extent that sick people are also motived by the need to understand their existence that has been disturbed by illness. The contact of the humanities, all those forms of expression that touch on the human condition, is of substantial help to enabling caregivers to accompany sick people so that the latter can put words to their lived experience. The humanities help to reduce the gap between the medical world and the lived experience. And the text of Heesters represents a good example.
\end{abstract}

\section{Keywords}

healthcare, sick, phenomenology, humanities

Affiliations des auteurs / Author Affiliations

${ }^{1}$ Faculté de médecine et des sciences de la santé, Bureau du développement de l'éthique, Université de Sherbrooke, Sherbrooke, Canada

\section{Correspondance / Correspondence}

Jacques Quintin, Jacques.Quintin@usherbrooke.ca

\section{Conflit d'intérêts}

Aucun declaré

\section{Conflicts of Interest}

None declared

The worlds of healthcare providers and sick people are different worlds, on parallel tracks that may sometimes be impossible to connect: one is founded on medical knowledge and the other on lived experience and life story. And this can lead to misunderstandings between these two universes of meaning. As Toombs emphasized, the world of sick people is characterized, according to a phenomenological perspective, by shrinking possibilities, even impoverishment [1]. This may be difficult to understand if we have not had such an experience of disease ourselves. Of course, healthcare providers do not need to understand the subjective experience of heart failure to understand its objective parameters, nor is it necessary for psychiatrists to suffer from depression to understand its signs and symptoms. According to my own experience on the ground and as a teacher, young healthcare providers often hear older sick people say that they know nothing about life and that there is no advice that people with little experience of life can give them. They may well retort that they have enough knowledge to provide the necessary care. In short, there is a big gap between the world of sick people and the world of healthcare providers. The obvious question that arises is how to 
bridge this gap, which may seem impassable. Can we decrease the gap by cognitive reflection or conscious deliberation, or is personal experience the only way to pass from one world to another?

Disease is experienced as the intrusion of something foreign. Beyond our body, it is our existence that is hurt. In fact, when we are battling a new and crippling disease, the major change is the transformation of our understanding of ourselves. We do not recognize ourselves any more, we have lost our bearings. Life no longer appears to us in the same way. If worst comes to worst, for sick people, disease and even life can cease to have meaning. Sick people may need care, but they also need to understand. At this point, two questions arise. The first concerns the validity of consent to care in such a context. On what basis is consent given when sick people do not understand themselves anymore, no longer grasp the meaning of their own existence? The second question concerns healthcare providers' presumption that sick people only need to receive quality care. This effort to deliver care is certainly necessary, but we may wonder if it masks the existential distress hidden behind the intellectual understanding of disease and the treatment given. In this sense, the care environment, hospitals and various clinics, are places where healthcare providers and sick people put a lot of effort into "doing". But the "being" of caregivers and care receivers is very often left out of the equation.

Heesters' text [2] clearly shows that a personal experience of disease can create empathy, i.e., understanding of other people in their experience of life. Obviously, as caregivers we do not have the "luxury" of getting every disease. This is where the humanities (art, literature, music, dance, movies, etc.), as the depository of the traces of the depth of life, can be a great help. The humanities are windows into the human condition. They allow us to read "our self as another". In their company, we are surprised to discover new things about ourselves. In this sense, the humanities have something in common with disease: both can open us up to another world of meaning. They are there for the best. That is why some sick people could say that, ultimately, the disease saved them from a senseless life. They would not be what they are today without the ordeal of the disease. Even if initially the disease is experienced as an unpleasant surprise, another surprise emerges: the discovery that life can be lived differently, that life has more than one meaning, that a full life is a life full of meaning.

Consequently, caring should never be limited to only medical actions. Good care must take into account patients' lives in their existential questioning. Caregivers must support care receivers in their decision-making, which is founded in the lived story of each individual. Respect for the other becomes respect for each person's unique story. In this sense, autonomy is more than a simple principle, it is a relationship to oneself made possible by the testimony of others who experience this relationship. It is the discovery that our identity is a path towards something, the outcome of which we do not know. Autonomy is not a starting point, it is a quest. Whether it is in a dialogue with an artistic work or with another person, we need others to venture there.

In conclusion, far from keeping the world of the sick and the world of healthcare providers separate, the humanities provide a place for gathering and sharing. They allow people to pass from one world to another. Each world gets its meaning because the worlds are related. It is what we call understanding another person. Heesters' text helps us understand that behind the disease, there is a subject that suffers and wants to speak [2]. To this I would add that we should not wait to be invited to speak. We must take the floor. This becomes a political gesture. For that reason, the field of medicine is not reducible to scientific knowledge and technological advances. There is part of the truth of oneself that is in play and that we find in the humanities. Emphasizing a subject's position is an inseparable ethical and political issue. In short, it is necessary to create certain conditions of possibility to foster our subjectivity. Otherwise, there is great risk that the subject will die before his body declines. We also need the humanities to humanize caring so that sick people can use words that are closely related to their own experience of life and do not borrow from medical speech [3]. However, for sick people to be able to discover their own words, they also need the humanities or caregivers nourished by the humanities. 


\section{List of References}

1. Toombs, S. Kay 1993. The Meaning of Illness. A Phenomenological Account of the Different Perspective of Physician and Patient. Dordrecht: Kluwer Academic Publishers.

2. Heesters, A. M. 2013. Healthy as a trout - as delicate as a dragon-fly. BioéthiqueOnline $3 / 13$

3. Kleinman, A. 1988. The Illness Narratives: Suffering, Healing, and the Human Condition. Basic Books. 